Jurnal Tanah dan Air (Soil and Water Journal)

ISSN: 1411-5719(p): 2655-500X (e), Volume 17 Nomor 1 (Juni 2020): 37 - 44 (http://jurnal.upnyk.ac.id/index.php/ita/index)

\title{
ANALISIS KESESUAIAN LAHAN UNTUK TANAMAN KAKAO DAN \\ TANAMAN PADI SAWAH TADAH HUJAN DI DESA NGALANG, KECAMATAN GEDANGSARI, KABUPATEN GUNUNGKIDUL
}

\section{ANALYSIS OF LAND SUITABILITY FOR CACAO PLANTS AND RAINFED RICE PLANTS IN NGALANG VILLAGE SUB-DISTRICT GEDANGSARI GUNUNGKIDUL DISTRICT}

\author{
Adityarizqy Putradinantyo $^{\text {I) }}$, M. Kundarto ${ }^{2) *}$, Dyah Arbiwati $^{2)}$, \\ dan Lanjar Sudarto ${ }^{2)}$ \\ ${ }^{1)}$ Prodi Agroteknologi, Universitas Pembangunan Nasional Veteran Yogyakarta \\ 2) Prodi Ilmu Tanah, Universitas Pembangunan Nasional Veteran Yogyakarta \\ ${ }^{*}$ Corresponding author E - mail: mkundarto@gmail.com
}

\begin{abstract}
Large area of dry land in Ngalang Village are generally used for non-irrigation rice field and dry land farming. Cacao cultivation was left by the community because the productivity of cacao plantation was decreased. In addition, the productivity of rice that was planted in rainfed lands was not optimal. Analysis of land suitability was required to improve the land capabilities. The purposes of this research were to find out the land characteristics and to analysis the land suitability for cacao plants and rainfed rice plants in Ngalang Village. Survey method was chose in this reasearch, with purposive sampling method to determine the sample points based on land unit map formed by overlaying type of soil map and land slope map. Matching method is a method that use to know the land suitability class. Land characteristics in Ngalang Village are hilly landform, the type of soils generally is Inceptisol, and limited surface water availability. Based on the results of the analysis, the actual land suitability class for cacao plantation in Ngalang Village is N (not suitable) with limiting factors are water availability, soil depth, land slope, and land preparation. There are two classes of land suitability for rainfed rice plants in Ngalang Village, S3 (marginally suitable) with area 716,7 Ha $(48,4 \%)$ limiting factors are water availability, root complex, nutrient retention, nutrient availability, erosion hazard and land slope. Class $\mathrm{N}$ (not suitable) with area $764,3 \mathrm{Ha}(51,6 \%)$ limiting factors are root complex, erosion hazard, and land preparation.
\end{abstract}

Keywords: Cacao, Rice plants, Ngalang Village, Land Suitability, Land Characteristics

\begin{abstract}
ABSTRAK
Lahan kering yang luas di Desa Ngalang umumnya digunakan sebagai tegalan atau sawah nonirigasi. Budidaya tanaman kakao mulai ditinggalkan oleh warga karna produksinya menurun. Selain itu, penggunaan sawah non-irigasi yang ditanami tanaman padi hasilnya belum optimal. Untuk memperbaiki atau meningkatkan kemampuan lahan diperlukan adanya analisis kesesuaian lahan. Tujuan dari penelitian ini adalah mengetahui karakteristik lahan dan menganalisis kesesuaian lahan untuk tanaman kakao dan tanaman padi di Desa Ngalang. Metode yang digunakan dalam penelitian ini adalah metode survey, dengan penentuan titik sampel menggunakan metode purposive berdasarkan satuan peta lahan yang dibentuk dari hasil overlay peta jenis tanah dan peta kemiringan lereng. Untuk analisis data dengan menggunakan
\end{abstract}


metode pembandingan (matching) antara data karakteristik lahan dengan kriteria kesesuaian lahan. Karakteristik Desa Ngalang memiliki bentuk lahan berbukit, jenis tanah didominasi oleh tanah Inceptisol, dan ketersediaan air permukaan yang rendah. Berdasarkan hasil analisis dapat diketahui bahwa kelas kesesuaian lahan aktual untuk tanaman kakao di seluruh Desa Ngalang termasuk kelas $\mathrm{N}$ (tidak sesuai) dengan faktor pembatas ketersediaan air, kedalaman tanah, kemiringan lereng, dan penyiapan lahan. Terdapat dua kelas kesesuaian lahan aktual untuk tanaman padi sawah tadah hujan di Desa Ngalang, yaitu kelas S3 (sesuai marginal) seluas 716,7 Ha atau $(48,4 \%)$ dengan faktor pembatas ketersediaan air, media perakaran, retensi hara, hara tersedia, bahaya erosi dan kemiringan lereng. Kelas N seluas 764,3 Ha $(51,6 \%)$ dengan faktor pembatas media perakaran, bahaya erosi dan penyiapan lahan.

Kata kunci: kakao, padi, desa ngalang, kesesuaian lahan, karakteristik lahan

\section{PENDAHULUAN}

Penggunaan lahan pertanian di Desa Ngalang didominasi oleh lahan sawah nonirigasi dan lahan tegalan karena lahan di Desa Ngalang termasuk lahan kering. Komoditas yang banyak dibudidayakan di Desa Ngalang antara lain adalah padi dan tanaman palawija. Tanaman tahunan yang banyak di Desa Ngalang adalah jenis tanaman kayu-kayuan. Tanaman kakao (Theobroma cacao L.) merupakan salah satu komoditas andalan perkebunan yang memiliki peran penting bagi perekonomian nasional, khususnya sebagai sumber pendapatan dan sumber devisa negara. Salah satu dusun di Desa Ngalang yang membudidayakan tanaman kakao adalah Dusun Karang. Namun, usaha budidaya di dusun tersebut saat ini tidak dilanjutkan, karena terjadinya penurunan produksi hasil kakao menurut warga sekitar. Menurut Badan Pusat Statistik Kabupaten Gunungkidul (2017) Kecamatan Gedangsari merupakan salah satu kecamatan yang memproduksi tanaman padi dengan hasil terbesar, tercatat luas panen 3274,7 ha. Dengan ini menjadi dasar bahwa ekstensifikasi lahan untuk tanaman padi (Oryza sativa L.) di Kecamatan Gedangsari, khususnya di Desa Ngalang sangat memungkinkan guna menunjang kemandirian pangan di tingkat Desa.Tingkat kesesuaian suatu lahan terhadap tanaman sangat berpengaruh kepada hasil produksi dan kualitas produksi dari suatu tanaman, dan untuk mengetahui tingkat kesesuaian lahan diperlukan adanya analisis kesesuaian lahan. Analisis kesesuaian lahan adalah suatu proses menilai sumber daya lahan berdasarkan karakteristik lahan yang dianalisis atau diamati untuk tujuan tertentu, dalam hal ini ditujukkan untuk pengembangan perkebunan kakao sehingga dapat meningkatkan perekonomian masyarakat dan melakukan perluasan lahan atau ekstensifikasi lahan komoditas padi untuk menunjang kemandirian pangan. Analisis kesesuaian lahan adalah membandingkan persyaratan yang diminta oleh tipe penggunaan lahan yang akan diterapkan, dengan sifat - sifat atau kualitas lahan yang dimiliki oleh lahan yang akan digunakan (Hardjowigeno dan Widiatmaka, 2011). Penelitian ini bertujuan untuk mengetahui karakteristik lahan Desa Ngalang dan mengetahui kesesuaian lahan untuk tanaman kakao dan padi sawah tadah hujan.

\section{BAHAN DAN METODE}

Penelitian ini dilaksanakan di Desa Ngalang, Kecamatan Gedangsari, Kabupaten Gunungkidul, Daerah Istimewa Yogyakarta. Metode yang digunakan dalam penelitian ini adalah metode survey untuk mengetahui kondisi umum wilayah dan penentuan titik 
sampel berdasarkan Satuan Peta Lahan yang dibuat dengan cara overlay peta jenis tanah dan peta kemiringan lereng. Penentuan titik sampel menggunakan metode purposive sampling, dan metode analisis yang digunakan adalah matching (membandingkan).

\section{HASIL DAN PEMBAHASAN}

Kondisi lingkungan yang dapat mendukung pertumbuhan tanaman kakao diantaranya adalah curah hujan $1.100-3.000 \mathrm{~mm} / \mathrm{tahun}$, dengan suhu $25-26^{\circ} \mathrm{C}$. Kedalaman tanah $>100 \mathrm{~cm}, \mathrm{pH} 6-7,5$, kandungan bahan organik tanah $>1,2 \%$, dan dengan kadar pertukaran kation $>24 \mathrm{cmol} / \mathrm{kg}$. Berdasarkan hasil penelitian dan mengacu pada kriteria kesesuaian lahan untuk tanaman kakao menurut BBSDLP (2011), dapat diketahui bahwa kesesuaian lahan untuk tanaman kakao di seluruh Desa Ngalang termasuk kedalam kelas $\mathrm{N}$ (tidak sesuai) dengan beberapa faktor pembatas diantaranya adalah lamanya masa kering (wa), kedalaman tanah (rc), kemiringan lereng (eh), dan singkapan batuan (lp). Faktor pembatas lamanya masa kering (wa) mempengaruhi terhadap ketersediaan air dan kelembapan di lapangan. Dibutuhkan tanaman kakao dengan genotipe yang tahan terhadap kondisi kekeringan dengan waktu yang lama, seperti pada penelitian Towaha J. dan Wardiana E. (2015) terdapat beberapa jenis genotipe tanaman kakao yang tahan terhadap kondisi bulan kering selama 6 bulan berturut-turut. Faktor pembatas kedalaman tanah (rc) yang dangkal berpengaruh terhadap peredaran akar tanaman kakao di dalam tanah. Tanah yang berada di Desa Ngalang umumnya adalah tanah yang belum berkembang secara lebih lanjut, lapisan padas dapat ditemui pada kedalaman tanah yang dangkal. Untuk mengatasi faktor pembatas ini dibutuhkan adanya pengolahan tanah menggunakan alsintan untuk menambah kedalaman tanah. Desa Ngalang merupakan desa dengan landform berbukit, kemiringan lereng (eh) yang curam menjadi salah satu faktor pembatas yang perlu diatas untuk meningkatkan kesesuaian lahan untuk tanaman kakao. Menurut Kartasapoetra (1987) kemiringan lereng yang curam dapat dikatakan lebih mudah terganggu atau rusak. Selain itu dengan kemiringan lereng yang curam, akan sulit untuk melakukan perawatan terhadap tanaman kakao yang dibudidayakan. Sehingga perlu dilakukan perbaikan, salah satu upaya yang dapat dilakukan untuk memperbaiki faktor pembatas ini adalah pembuatan terasering atau dengan pembuatan teras individu untuk tanaman kakao. Faktor pembatas lainnya yang perlu diperbaiki agar dapat meningkatkan kelas kesesuaian lahan untuk tanaman kakao adalah singkapan batuan (lp). Singkapan batuan yang luas/banyak di suatu lahan menyebabkan sulitnya dalam melaksanakan pengolahan lahan. Sehingga perlu diatasi dengan penggunaan alsintan untuk menyingkirkan atau mengurangi singkapan batuan di suatu lahan. Berdasarkan hasil penelitian dapat diketahui luasan lahan pada tiap kategori kelas kesesuaian lahan yang disajikan pada Tabel 1.

Kondisi lingkungan yang dapat mendukung pertumbuhan tanaman padi yang dibudidayakan secara sawah tadah hujan adalah sebagai berikut, ketinggian tempat $0-$ $1500 \mathrm{mdpl}$, suhu $24-29^{\circ} \mathrm{C}$, berada pada zona agroklimat B (jumlah bulan basah 7-9 bulan). Kondisi media tumbuh yang dapat mendukung pertumbuhan tanaman padi antara lain, kedalaman tanah $>50 \mathrm{~cm}$, kadar pertukaran kation $>16 \mathrm{cmol} / \mathrm{kg}, \mathrm{pH}$ tanah $5,5-8,2$, dengan kandungan bahan organik $>1,2 \%$. 
Tabel 1 Kesesuaian Lahan Aktual Kakao

\begin{tabular}{ccc}
\hline No & Kelas & Luas (Ha) \\
\hline 1 & Nwa & 534,5 \\
2 & Nwa,rc,eh & 491,6 \\
3 & Nwa,rc & 217,3 \\
4 & Nwa,eh & 171,4 \\
5 & Nwa,rc,lp & 66,2 \\
\hline \multicolumn{2}{c}{ Total Luas } & 1481 \\
\hline
\end{tabular}

Berdasarkan penelitian yang telah dilakukan dan mengacu pada kriteria kesesuaian lahan untuk tanaman padi sawah tadah hujan menurut BBSDLP (2011), dapat diketahui bahwa kesesuaian lahan untuk tanaman padi sawah tadah hujan di Desa Ngalang terbagi menjadi dua kelas, S3 (sesuai marginal) dan N (tidak sesuai). Beberapa faktor yang menjadi pembatas untuk kesesuaian lahan tanaman padi sawah tadah hujan antara lain adalah zona agroklimat (wa), kedalaman tanah (rc), bahan kasar (rc), hara tersedia (na), C-Organik (nr), kejenuhan basa (nr), kemiringan lereng (eh), dan singkapan batuan (lp). Pada karakterisitk ketersediaan air (wa) yang menjadi faktor pembatas adalah zona agroklimat. Zona agroklimat ditentukan oleh jumlah bulan basah secara berturut-turut pada satu lokasi. Desa Ngalang termasuk kedalam zona agroklimat C3 (6 bulan basah dan 6 bulan kering). Faktor pembatas ini tidak dapat diperbaiki karna sulitnya ketersediaan air permukaan di Desa Ngalang sehingga tidak dapat menyediakan saluran irigasi untuk lahan sawah. Pada karakteristik media perakaran (rc) beberapa parameter yang menjadi faktor pembatas diantaranya adalah kedalaman tanah dan bahan kasar. Beberapa faktor pembatas tersebut dapat mempengaruhi pertumbuhan tanaman karna mengganggu peredaran akar di dalam tanah. Upaya yang dapat dilakukan untuk memperbaiki faktor pembatas tersebut adalah melakukan pengolahan tanah dengan menggunakan alsintan sehingga dapat menambah kedalaman tanah dan mengurangi bahan kasar pada media perakaran.

Pada karakteristik hara tersedia (na) parameter yang menjadi faktor pembatas adalah ketersediaan $\mathrm{N}$-total, $\mathrm{P}_{2} \mathrm{O}_{5}$, dan $\mathrm{K}_{2} \mathrm{O}$ di dalam tanah. Ketersediaan unsur yang terbatas sangat berpengaruh pada pertumbuhan dan hasil produksi tanaman padi. Upaya yang dapat dilakukan untuk memperbaiki faktor pembatas tersebut adalah penambahan pupuk yang sesuai dengan kebutuhan tanaman dan sesuai dengan anjuran dosis. Pada karakteristik retensi hara, parameter yang menjadi faktor pembatas adalah C-Organik dan kejenuhan basa. Kandungan C-Organik yang rendah di lahan di Desa Ngalang dapat dikarenakan tanah tergolong tanah muda atau belum berkembang lebih lanjut dan belum adanya penambahan C-Organik dari biomassa yang dihasilkan oleh vegetasi di lahan tersebut. Penambahan pupuk organik dapat meningkatkan kadar C-Organik tanah. Kejenuhan basa yang rendah pada beberapa lahan di Desa Ngalang terdapat pada lahan dengan jenis tanah alfisol, dan lahan tersebut memiliki $\mathrm{pH}$ yang rendah. Untuk meningkatkan kejenuhan basa tanah dapat dilakukan dengan penambahan kapur/dolomit atau dengan menambahkan pupuk organik. Pada karakteristik bahaya erosi (eh) parameter yang menjadi faktor pembatas dalam budidaya tanaman padi sawah tadah hujan adalah kemiringan lereng. Penanaman tanaman padi membutuhkan kemiringan lereng yang datar hingga landai, karena pada kondisi kemiringan lereng curam akan menyebabkan tanah mudah tererosi. Untuk mengatasi faktor pembatas dapat dilakukan pembuatan terasering. 
Pada karakteristik penyiapan lahan (lp) faktor yang menjadi pembatas adalah parameter singkapan batuan. Singkapan batuan yang tersebar di beberapa satuan lahan tergolong luas. Hal ini dapat mengurangi luas bidang olah untuk budidaya tanaman padi. Untuk mengatasi faktor pembatas tersebut dapat dilakukan pengolahan lahan menggunakan alat mesin pertanian dengan mengangkat singkapan batuan atau menghancurkan singkapan batuan di suatu lahan. Berdasarkan hasil penelitian dapat diketahui kelas kesesuaian lahan untuk tanaman padi sawah tadah hujan beserta luasannya di Desa Ngalang, disajikan pada tabel 2.

Penelitian ini juga menghasilkan peta kesesuaian lahan aktual untuk tanaman kakao (Gambar 1) dan tanaman padi sawah tadah hujan (Gambar 2), sehingga dapat diketahui wilayah di Desa Ngalang yang berpotensi untuk ditanami tanaman kakao dan padi sawah tadah hujan setelah dilakukan perbaikan terkait faktor pembatas pada masing-masing lahan.

Tabel 2. Kesesuaian Lahan Aktual Padi Sawah Tadah Hujan

\begin{tabular}{ccc}
\hline No & Kelas & Luas (Ha) \\
\hline 1 & S3wa,na & 204 \\
2 & S3wa,na,eh & 109 \\
3 & S3wa,nr,na & 25,1 \\
4 & S3wa,nr,na,lp & 146 \\
5 & S3wa,nr,na,eh & 232,6 \\
6 & Neh & 626,8 \\
7 & Nrc,pl & 51,1 \\
8 & Nrc,eh & 71,3 \\
9 & Nrc,eh,lp & 15,1 \\
\hline \multicolumn{2}{c}{ Total Luas }
\end{tabular}

\section{KESIMPULAN}

1. Berdasarkan hasil survey yang dilakukan di Desa Ngalang, desa ini memiliki luas $1.481 \mathrm{Ha}$ atau $14,81 \mathrm{~km}^{2}$. Topografi atau landform di Desa Ngalang umumnya berbukit. Jenis tanah yang mendominasi di Desa Ngalang adalah jenis tanah Inceptisol. Desa Ngalang memiliki rata-rata curah hujan tahunan yang tergolong rendah. Solum tanah yang umumnya dangkal juga dapat menjadi faktor pembatas bagi kegiatan pertanian.

2. Kelas kesesuaian lahan aktual untuk tanaman kakao di seluruh Desa Ngalang adalah kelas N (tidak sesuai) yang dibatasi oleh beberapa faktor, diantaranya ketersediaan air (wa), media perakaran (rc), bahaya erosi (eh), dan penyiapan lahan (lp).

3. Kelas kesesuaian lahan aktual untuk tanaman padi sawah tadah hujan di Desa Ngalang terbagi menjadi dua kelas yaitu kelas S3 (sesuai marginal) dan kelas $\mathrm{N}$ (tidak sesuai) yang dibatasi oleh beberapa faktor, diantaranya karakteristik ketersediaan air (wa), media perakaran (rc), retensi hara (nr), hara tersedia (na), bahaya erosi (eh), dan penyiapan lahan (lp). 


\section{DAFTAR PUSTAKA}

Anonim. 2017. Gunungkidul dalam Angka 2017. Badan Pusat Statistik Gunungkidul. Yogyakarta: CV. Taman Bunga

Hardjowigeno, S. dan Widiatmaka. 2011. Evaluasi Kesesuaian Lahan dan Perencanaan Tataguna Lahan. Yogyakarta: UGM Press

Ritung, S., Kusumo N., Anny M., dan Erna S. 2011. Petunjuk Teknis Evaluasi Lahan untuk Komoditas Pertanian. Balai Besar Penelitian dan Pengembangan Sumberdaya Lahan Pertanian. Bogor: Badan Penelitian dan Pengembangan Pertanian

Towaha J. dan Wardiana E. 2015. Evaluasi Tingkat Toleransi 35 Genotipe Kakao Terhadap Periode Kering. Jurnal. Sukabumi 

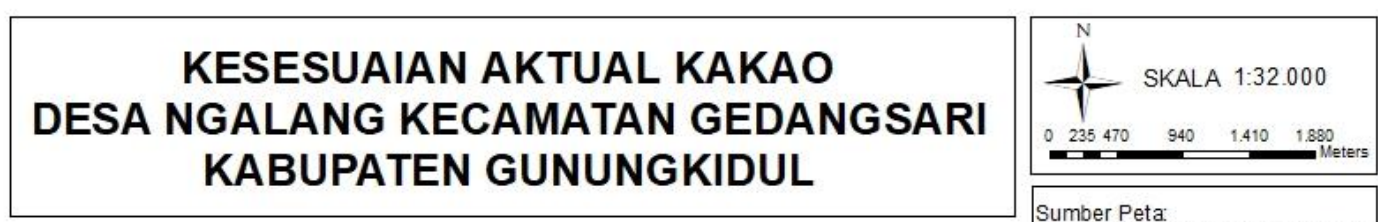

Sumber Peta:

1. Peta Rupa Bumi Skala 1:25.000 2. Peta Tanah Bappeda

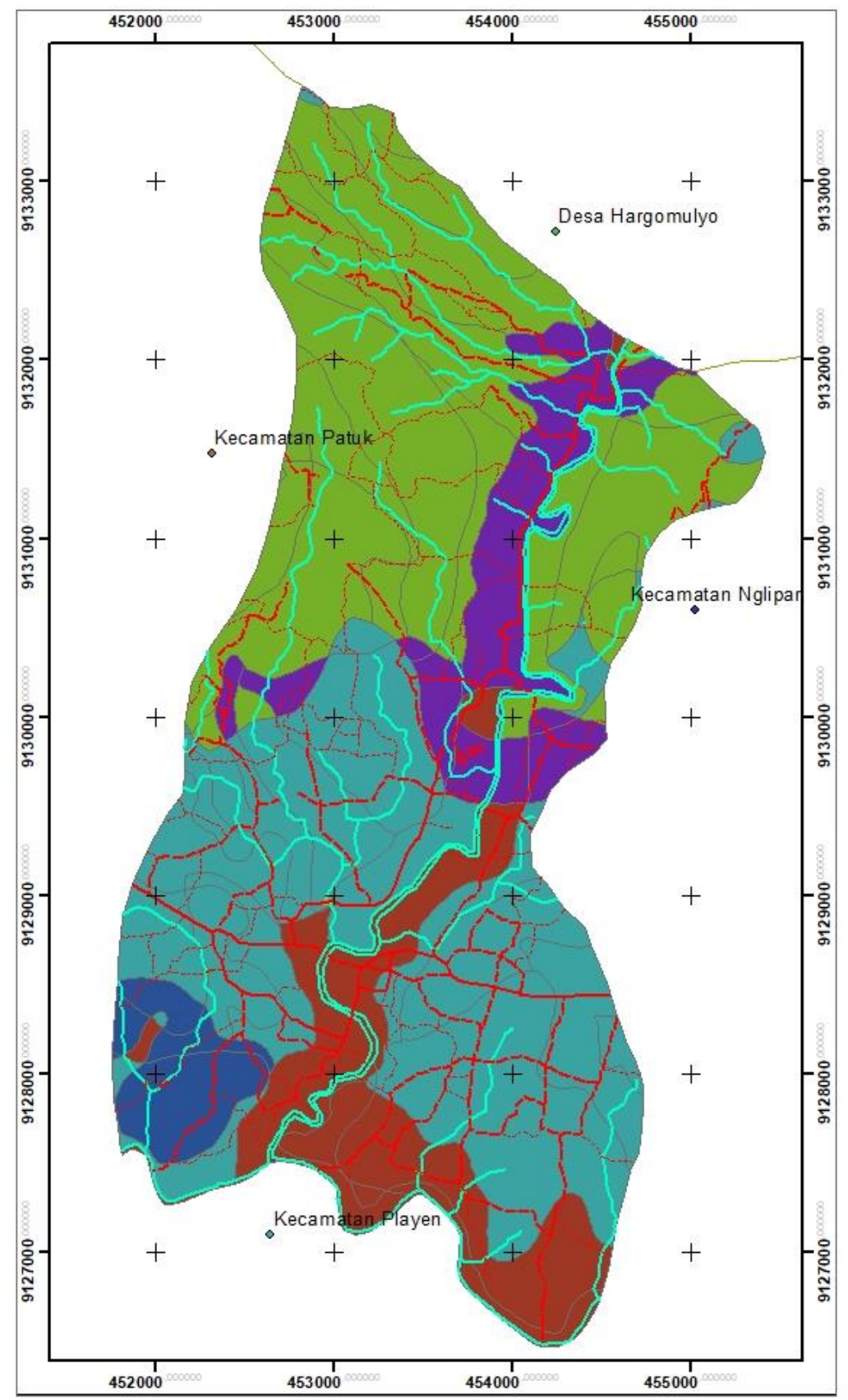

Kab. Gunungkidul

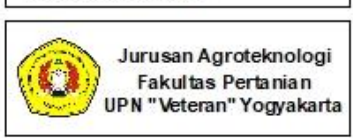

Disusun Oleh: Adityarizqy Putradinantyo 134150058

Legenda

KETERAN GAN

- Gorong-gorong Jalan Lain

- Gorong-gorong Lokal

_ Jalan Kolektor

--- Jalan Lain

— Jalan Lokal

...-.. Jalan Setapak

KESESUAIAN AKTUAL

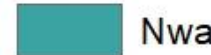

Nwa,eh

Nwa,rc

Nwa,rc,eh

Nwa,rc,lp

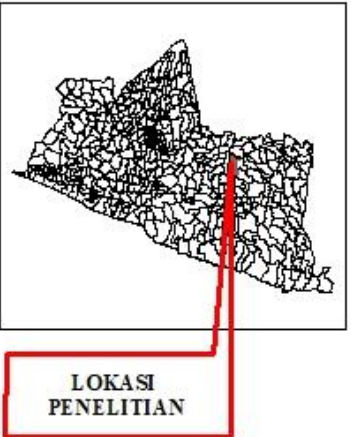

Gambar 1 Peta Kesesuaian Lahan Aktual Untuk Tanaman Kakao 


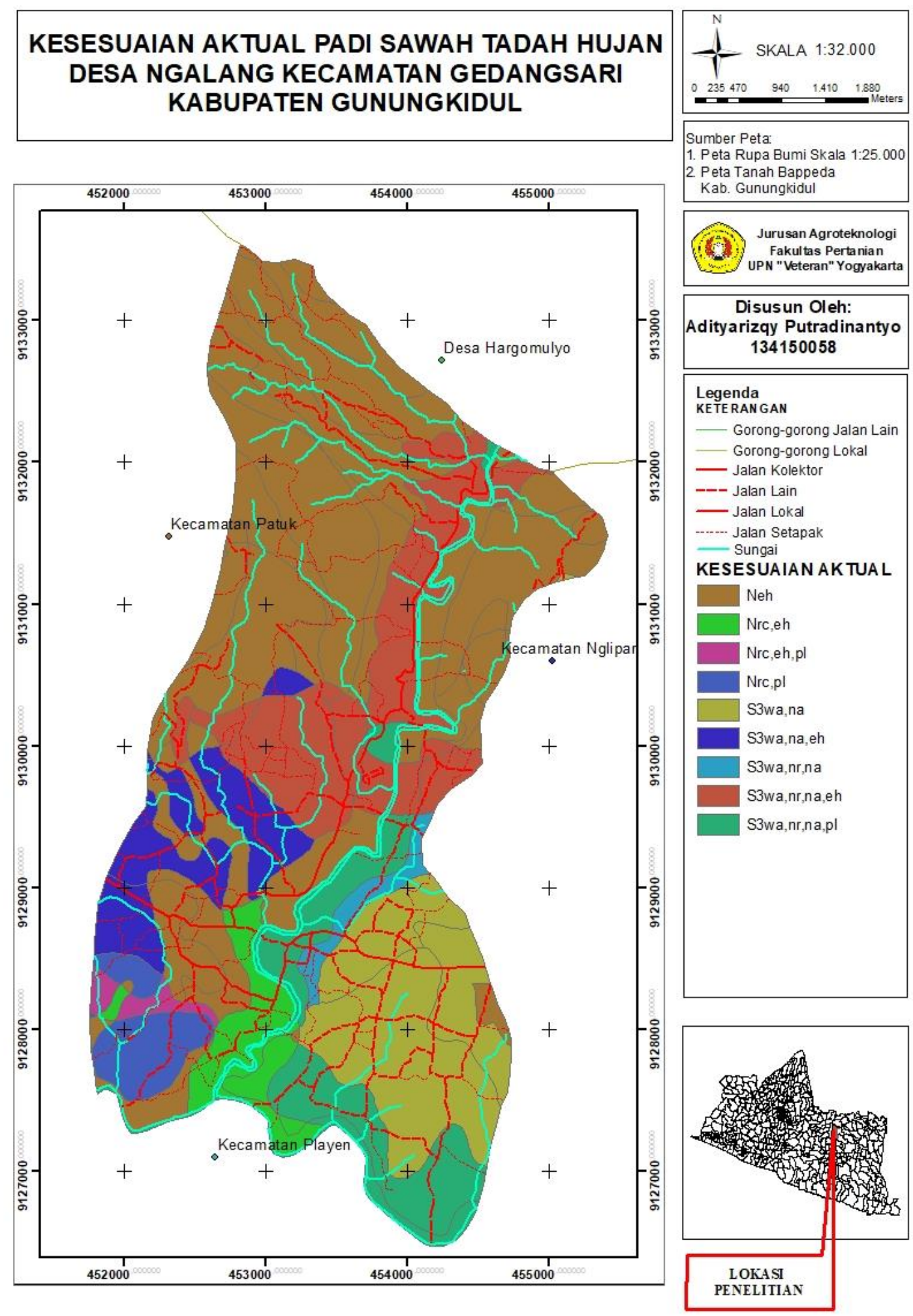

Gambar 2 Peta Kesesuaian Lahan Aktual Untuk Tanaman Padi Sawah Tadah Hujan 